\title{
The Effect of Product Innovation, Product Quality And City Image on Purchase Decision of Uis Karo Woven Fabric
}

\author{
Maretta Ginting \\ Departement of Management \\ Universitas Sumtera Utara \\ Medan, Indonesia \\ gintingmaretta11@gmail.com
}

\begin{abstract}
Uis Karo is Indonesian traditional woven cloth that comes from the Karo Region of North Sumatera. The purpose of this research is to determine and analyze the effect of product innovation, product quality and city image on buying decision of Uis Karo at Tourism Object of Berastagi of North Sumatera. Data collection in this research was conducted through a survey approach with quantitative descriptive research type by distributing questionnaires to 95 people. Data collection was done by interviews, questionnaires and documentation studies. The method of data analysis used is multiple linear regression using SPSS software. The results showed that simultaneously product innovation, product quality and the image of the city have positive and significant influence on the buying decision of Uis Karo. Partially each, product innovation, product quality and city image have a positive and significant effect on purchasing decision of Uis Karo.
\end{abstract}

Keywords-tourism attraction; product innovation; product quality; city image; purchasing decision

\section{INTRODUCTION}

Small Medium enterprise (SMEs) has important role in the national economic development of Indonesia. Its seen from the contribution sector of small medium enterprises (SMEs) to domestic product increase from 57,84 percent to 60,34 percent in the five years lately (2011-2016). The employment in this sector also increased from 96,99 percent goes to 97,22 percent in the same period of times.

In the Area of Karo, only a few large and medium industrial cities absorb more than 100 employees. Most of them are small industries and homemade which 5-19 employees and 1-4 employees.

\author{
Hendri Sembiring \\ Departement of Management \\ STIE IBBI \\ Medan, Indonesia \\ sembiringhendri745@yahoo.com
}

TABLE 1

Number of small medium enterprises in the Area of Karo

\begin{tabular}{|c|c|c|}
\hline & Year & Number of SMEs \\
\hline 1 & 2010 & 27164 \\
\hline 2 & 2011 & 17802 \\
\hline 3 & 2012 & 125166 \\
\hline 4 & 2013 & 389544 \\
\hline 5 & 2014 & 547086 \\
\hline
\end{tabular}

Source: Karo Statistic, 2016

In the first Table 1, its show that numbers of medium enterprises in Karo areas quite rapidly developed from 2010 until 2014 there was a significant increase in the number of small medium enterprise[19].

Weaving is one of Indonesia's heritage passed down from generation to generation. Weaving is closely related to the arts and culture in on area so that usually the motifs or images weaving in each symbol that are in tune with the culture of a region. Weaving Karo is one of the weavings done by the society spread in the areas of North Sumatera. Weaving Karo rarely heard by people outside the Karo tribes, people outside more to known "Ulos Batak" then (UIS) weaving Karo, even people often think that Karo weaving is from Ulos Batak. Although it has a very significant differences, especially in terms of motifs (design) or images that common different symbols in each motif.

Government regulation state No.50/2010 that tourist attractions comprise of natural tourist, attractions of cultural attractions and manmade tourist attractions. Weaving Uis Karo is one of the tourist attractions that are included in the attraction of cultural tourism and human-made attraction.

Purchase decisions as an integration process that combines knowledge to evaluate two or more alternative behaviors and choose one of them. If consumers do not have experience with a product, they tend to trust a brand that is liked or famous. Purchasing decisions are a fundamental part of consumer behavior that leads to the purchase of goods and services to meet their needs either by paying or exchanging goods they own. An increase in purchasing decisions of good and service is expected by the producers because it can automatically increase the company's profit. 
In 2013, production capacity per year around 25.000 sheets weaving Uis Karo. And do not increase of significant for four years lately. In 2016, production capacity 30.000 sheets. In matter indicates that the demand level of Karo weaving does not increase significantly that production cannot be at the level.

Product innovation is the thing that must be done by the engaged business industry including weaving industry especially product innovation. During this industry weaving in Indonesia especially only oriented to the form that never changed it's shaped only cloth sheet without continuous product innovation color, designs and motifs are also mostly still as derived by the ancestors based on the values, understanding culture adopted. As well as weaving Karo products has not been much innovation that mode the majority only in the form of cloth sheets with patterns motifs from a long time ago did not change. In this case, the impact on consumer interest and its continuation impact on the low level of sales.

In 2007, NKC (National Committee Knowledge) state that innovation allows small business to compete with big cities. But there are many small towns in Indonesia that aren't aware of the important role of innovation. They consider that innovation only happens in big cities because it has enough money to do innovation development. Its often experienced Karo weavers in Karo Areas they are less aware of the importance of the role of product innovation in increasing consumer interest in their products.

The image of the city weaving business in Karo Areas spreads of Tongging and Sikodon-Kodon Area, Merek, Kabanjahe, and Berastagi. The Total of weavers as 50 persons, the commodity result was weaving of nipes. The weaving of Bekabuluh and weaving of jongkit and so on production capacity around 25000 sheets per year (Dep. Economic Enterprises Karo, 2013.

\section{TABLE 2}

The Total of weavers and weaving production in Karo on 2013-2016

\begin{tabular}{|c|c|c|}
\hline Year & Number of Weavers & $\begin{array}{c}\text { Number of Woven } \\
\text { ( Sheets) }\end{array}$ \\
\hline 2013 & 50 & 25,000 \\
\hline 2014 & 50 & 25,000 \\
\hline 2015 & 65 & 30,000 \\
\hline 2016 & 65 & 30,000 \\
\hline
\end{tabular}

Source: Economic Enterprises Department and Trade in Karo Areas, 2013 and the amount of BPS 2016

In Table 2, show that amount of weavers in 2013 only 50 employees with production capacity per year 25,000 sheets of weaving Karo. And not increase in significantly for 4 years lately. In 2016, only 65 employees with production capacity 30,000 sheets each year. [9].

The comparative of amount of weavers and amount of production ulos Batak Toba. Which results of weavers of Ulos Batak in Toba Samosir areas at amount of weavers and production total of weaving relative more than less.
TABLE 3

The Total of Weavers and Production of Ulos in Toba Samosir

\begin{tabular}{|c|c|}
\hline $\begin{array}{c}\text { Number of weavers } \\
\text { Number of woven } \\
\text { (Sheets) }\end{array}$ \\
\hline 404 & 126,048 \\
\hline
\end{tabular}

Source: Statistic Tiba Samosir , 2016

In third table, shows that amount of weavers Ulos Batak in Toba Samosir reach 404 total amount with production capacity 12.048 sheets weaving Ulos Batak. Society in Toba Samosir realizes the Ulos weaving business is a small business that has a huge opportunities because in accordance with the needs of customs events and people who are not tribes of Batak also want to have Ulos for their collection,[43].

Based on the background that has been described previously researchers interested in conducting research entitled: "The Effect Of Uis Karo Woven As Tourism Attraction Towards Purchasing Decision of Visitors In Tourism Object In Berastagi Of North Sumatera".

\section{Research purposes:}

To analyze the effect of product innovation, product quality and image of the city toward purchasing decision of visitors in tourism object Berastagi of North Sumatera

Benefits of research

1. For tourism object Berastagi North Sumatera as input in seeing the effect of product innovation product, quality product and image of the city on purchasing decisions at the object of Berastagi North Sumatera.

2. For the Doctoral program in some case to be used and develop.

3. For researchers to apply the knowledge geared in college and broaden the research horizons.

4. For further researcher as a reference in doing research especially about the effect of product innovation, product quality and city image to the purchasing decisions.

\section{LITERATURE REVIEW}

\section{A. $\quad$ Visitor Decisions}

Purchasing decision is in integration process with knowledge combination two or more alternative behaviors and chooses one of them [34]. In general, customer buying decision was buy the most prefered brand [22]. Defenition of decision was the selection toward 2 alternative or more[36]. Complicated decision making process often involves some decisions. It always requires choice among several different behaviors.

\section{B. Product Innovation}

Innovation is something new but has some level associated with this types of innovation. It is divided incremental radical 
and revolutionary. Incremental innovation is an innovation that takes small steps in the innovation process. Radical innovation is an innovation which changed almost everything about the product, process or special organization and revolutioner innovation is innovation that found a new breakthrough that previously did not exist [30]

\section{C. $\quad$ Product Quality}

The meaning of product quality based on [24] is the ability of a product to demon store its function, this includes the overall durability, reliability the accuracy of ease of operations and reparation of products as well as other product attributes. Product quality as a product or service that meets customer expectation [23].. Based on the definition according to experts can be concluded that the quality of the product is a form of goods or services measured in the level of quality standard reliability, the added privilege of flavor and performance function of the product that can meet customer's expansion.

\section{Conceptual Framework}

Product is one important aspect in the consumer's decision to buy product is also one of the decisive variables in the activities of business. Without the product, a business cannot perform activities to achieve the expected results. Each company must be developed new products. New product development has an effect on purchasing decision. Based on [2] " Product development is the creation of new products that can be marketed6 and the process of new products that can be marketed and the process of changing applications for new technologies into marketable products.

The way to complete effectively is to provide consumers with better needs than competitors. Innovation as a result of competing for aggressiveness is the fastest thing required to meet the challenges of competitors. So it can be said that product innovation affects the purchasing decision there for the company innovates with the aim that interest of customers who buy more and more products.

Product innovation is closely linked to the creation of new products are stimulates consumers to try the product. Most of the innovators are cities whose customers have confidence in their products or cities. The most important is to create a new product that can meet the needs and desires of consumers and so arise interested in purchasing the product is expected to be realized through purchasing decisions [31].

Product quality is a potential strategic weapon to beat competitors, the company with the best product quality that will grow rapidly and in the long run the company will be more successful than other companies. The higher degree of product compatibility with standard quality specifications than have been established the higher quality of the product concerned [22].

The relationship of product quality to consumers purchase decision is that quality can be expressed as the expectations and perceptions of consumer's as good as actual performance. The quality of the product must be consistent with that promised by all activities in the marketing mix for potential consumers of this product quality should be communicated well because it can build consumer satisfaction to buy the products in question.

The corporate image is a name sign, symbol, design or combination of all of this which is intended to recognize the product or service of a person whose group of sellers and to distinguish from a competitor's product or to say something related to a promise of acceptance of trust and hope, so that a city image of a strong product will make its customers feel more comfortable and secure when they buy the products [22]. .City image is a recognizable entity and promises certain values. City image can also be interpreted as the name of the term, design, symbols or combinations that identify a product or service produced by a city. This identification also server to differentiate with products offered by competing cities, and then described the conceptual framework used as the basis of the research flow as follows:

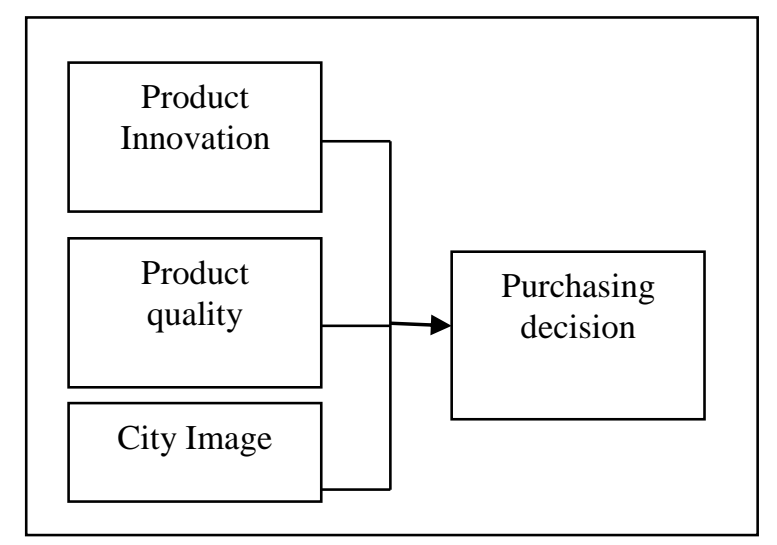

Picture 1. Conceptual Framework

\section{E. Hypothesis}

Product innovation, product quality and city image influence to decision of purchasing weaving Uis Karo at Berastagi Tour in North Sumatera.

\section{RESEARCH METHODS}

\section{A. Population and Sample}

Populations in this study are all visitors' attractions Berastagi North Sumatera who ever made a purchase weaving Uis Karo at the object Berastagi Tour. Sample selection is done by purposive sampling, where technique of determination of sample done with certain consideration. The sample of the respondents in this study is the visitor's attraction Berastagi Tour and not the local person population of 100 persons.

\section{B. Operational Definition}

In this research, divided 3 of independent variables, including to product innovation (X1), product quality (X2), and city image (X3) then dependent variables are decision purchase (Y). 


\section{Method Data Analyze}

Data analysis method in this research is using multiple regression with model to know how big influence of product innovation, product quality and city image to decision of purchasing of visitors at Berastagi. Researchers used to help with SPSS (Statistic Product and Service Solution) using multiple linear regressions formulated as follow:

$$
\mathrm{Y}=\alpha+\beta_{1} \mathrm{X}_{1}+\beta_{2} \mathrm{X}_{2}+\beta_{3} \mathrm{X}_{3}+\varepsilon
$$
D. Hypotheses test:
a. Simulant test (F test)
b. Partial test (T-test)
c. Coefficient of determination $\left(\mathrm{R}^{2}\right)$

\section{RESULT AND DISCUSSION}

The influence of product innovation, product quality and city image towards the purchase decision of visitors on the tourist object Berastagi.

Based on multiple regression equation in this research was :

$$
\mathrm{Y}=3,225+0,393 \mathrm{X} 1+0,324 \mathrm{X} 2+0,263 \mathrm{X} 3
$$

\section{A. Coefficient of determination}

The magnitude of the effect of independent variables on the dependent variables is to use the following test coefficient of determination $\left(\mathrm{R}^{2}\right)$ as bellow:

\section{TABLE 4. Coefficient of Determination Test}

\begin{tabular}{ccccc}
\cline { 2 - 5 } Model & R & R Square & $\begin{array}{c}\text { Adjusted R } \\
\text { Square }\end{array}$ & $\begin{array}{c}\text { Std. Error of the } \\
\text { Estimate }\end{array}$ \\
\hline 1 & $.920^{\mathrm{a}}$ & .846 & .845 & .90617 \\
\hline
\end{tabular}

Source: Results from data processing, 2017

In table 4 obtained the score Adjusted R Square of 0,845 which means that product innovation (X1), product quality (X2) and city image (X3) can explain the variation of the purchase decisions of visitors amount to $84,5 \%$ and the rest $15,5 \%$ influenced by other variables outside of the variables studies such as service quality.

\section{B. $\quad$ F test (Simultaneous)}

In Table 5 reach the result of test $F$ count 697,980 with $F$ table in $\alpha=0,05$ and degree numerator 3 and degree denominator 371 reach $F$ table around 3, 23. So this result is known $\mathrm{F}$ count $>\mathrm{F}$ table and significant 0,000 or smaller than $\alpha=0,05$. This it can be concluded that $\mathrm{H}_{1}$ accepted which means product innovation, product quality and city image simultaneously have a significant effect on the purchase decision of visitors.
TABLE 5

F test (Simultaneous) ANOVA $^{\mathrm{b}}$

\begin{tabular}{ccrccc}
\hline Model & $\begin{array}{c}\text { Sum of } \\
\text { Squares }\end{array}$ & \multicolumn{1}{c}{ Df } & $\begin{array}{c}\text { Mean } \\
\text { Square }\end{array}$ & \multicolumn{1}{c}{ F } & Sig. \\
\hline 1 Regressio & 1675.088 & 3 & 558.363 & 679.980 & $.000^{\mathrm{a}}$ \\
\hline Residual & 304.645 & 371 & .821 & & \\
\hline Total & 1979.733 & 374 & & & \\
\hline
\end{tabular}

Source: Results from data processing, 2017

C. Ttest ( Partial)

TABLE 6

\begin{tabular}{|c|c|c|}
\hline Model & $\mathrm{T}$ & Sig. \\
\hline (Constant) & 3.302 & .001 \\
\hline $\begin{array}{l}\text { Product } \\
\text { Innovation }\end{array}$ & 10.761 & .000 \\
\hline Product Quality & 7.406 & .000 \\
\hline City Image & 5.918 & .000 \\
\hline
\end{tabular}

Results of T Test (Partial)

Sumber: Results from data processing, 2017

1. In table 6 , score $t$ count for product innovation $(10,761)$ larger then score of $\mathrm{t}$ table $(1,65)$ or score sig $\mathrm{t}$ for product innovation $(0,000)$ more smaller than alpha $(0,05)$. Based on this result it rejects $\mathrm{H}_{0}$ and accepts $\mathrm{H}_{1}$ for product innovation. This the product innovation, partially significant effect on the purchase decision of the visitors means product innovation here a significant effect in improving the purchase decision of visitors, of the results indicate that product innovation dominantly influences the purchasing decision of the visitors compared to product quality variable and city image. This shows the product innovation is more decisive in improving the purchase decision of visitors.

2. Score $\mathrm{t}$ count for product quality $(7,406)$ more large compare to score $\mathrm{t}$ table (1.65) or score sig $\mathrm{t}$ for product quality $(0,000)$ smaller than alpha $(0,05)$. Based on the result to reject Ho and accept $\mathrm{H}_{1}$ for quality product. This partially the quality significantly influence the purchase decision of visitors means that the quality of products formed with good will have a real impact on improving customer purchasing decisions.

3. Score $t$ count for image city $(5,918)$ larger then score $t$ table $(1,65)$ or score sig t for image city $(0,000)$ smaller than alpha $(0,05)$. Based on results it rejected $\mathrm{H}_{0}$ and accepted $\mathrm{H}_{1}$ for image city. This partially the image of the city has a significant effect on the decision of the purchase of visitors means that the image of a strategic 
and comfortable city will have a significant effect in improving the decision of visitors purchases.

\section{DISCUSSION}

The effect of product innovation, product quality and city image on purchasing decision.

Karo traditional clothes are certainly one of the results of Karo culture, therefore, as the culture evolutes. Karo people have many different kinds of clothes with different functions. Traditionally their governments are woven by a Karo woman using a kind of cotton swobs that are made into yarn and dyed with dye made from lime, kitchen ash, turmeric and tetep (a kind of plant)

The results of this research show simultaneously product innovation; product quality and image of city have positive and significant influence on purchasing decision, then partially each variable of its significant effect on purchasing decision.

Buying interest is derived from a learning process and thought process that forms a perception. The interest that comes in making a purchase creates a motivation that continues to record in his or her mind and becomes a very powerful activity that in the end when a consumer has to fulfills his need to actualize what is in his mind. The attractiveness of a conclusion that buying interest is still on attitude and in this phase, the consumer may not necessarily have taken a buying decision action

To be able to know the extent of consumer purchasing process, it would be necessary to attempt such as whether consumers need information about the product to be purchased or may need to be encouraged to make a purchase. Through the support of available information may also encourage a person to make a decision including purchased.

Generally a person is very national in utilizing the available information and considering the implications of the action before deciding to engage or not in the attitude.

The results of this research are supported by previous researcher [33]. The result showed that product innovation and preference to postpone purchases positively and significantly influence consumer purchasing decisions. Product innovation has a positive effect on future innovation. Like use future innovations have a positive effect on consumer preferences to de by purchases. However future innovations have a negative effect on consumer purchasing decisions.

The conclusion of the end of his research showed that the three variables of this study have a positive influence and significantly to the dependent variable purchase decision.

The research results can be seen that the four variables have more positive relationship and the stronger influence on consumer purchasing decisions[32]. The research results show that consumer attitudes (X) consisting of cultural social, personal and psychological variables together have on influence on purchasing decisions (Y). Consumer attitudes consisting of cultural and personal variables do not partially effect purchasing decisions $(\mathrm{Y})$, while social psychological variables partially influence purchasing decisions $(\mathrm{Y})$ [18]. .
Research conducted by [45]. proves that the image has a positive and significant impact on consumer loyalty. The results of these studies prove that customers who already have a positive image of a city will be more likely to choose the city as the first choice and will recommend it to others in the financial services industry especially the bank a good image will greatly affect the customer to make the city as the main choice.

\section{CONCLUSION}

1. Simultaneous test results show product innovation, product quality, and city image have a significant effect on purchasing decision.

2. Partially product innovation has a positive and significant effect on purchasing decision, product quality has positive and significant effect to purchasing decision. and city image has a positive and significant effect on purchasing decision.

\section{References}

[1] Anastasia Diana and Fandy TjiptonoFifth Edition.Total Quality Management (TQM). Yogyakarta: ANDI. . 2008.

[2] Arikunto. Suharsimi. Research Procedure: A Practice Approach. Revised Edition. Eighth Print. Jakarta: Rineka Cipta. 2006.

[3] Behjati, Barkhordari, Lookzadeh. Interrelation between E-service Quality and E-satisfaction and Loyalty. Journal European Journal of Business and Management Vol 4, No.9. 2012.

[4] Bielen, Frederic, Nathalie. Waiting Time Influence on The Satisfaction - Loyalty Relationship in Services. Managing Services Quality, Vol.17 No.2, pp.174-193. 2007.

[5] Bontis, Nick. and Lorne D. Booker. The mediating effect of organizational reputation on customer loyalty and service recommendation in Tourism Object Brastagi Sumatera Utara industry. Management Deion, Vol. 45, No. 9 p. 1426-1445. 2007.

[6] Calik, Nuri., And N. Figen Balta. Consumer satisfaction and loyalty derived from the perceived quality of individual Object of Brastagi Sumatera Utaraing services: A field study in Eskisehir from Turkey. Journal of Financial Service Marketing, Vol. 10 No. 4 p. 135-149. 2006.

[7] Charles W. Lamb, Joseph F. Carl McDaniel.. Marketing,. First edition , Salemba Empat, Jakarta, 2001

[8] Dimitriades, Zoe S. Customer satisfaction, loyalty and commitment in service Organizations. Management Research News, Vol. 29 No. 12, p. 782-800. 2006

[9] Economic Enterprises Department and Trade in Karo Areas, and the amount of BPS 2016.

[10] Foster, Brian D and John Q, Cadogan. Relationship Selling and Customer Loyalty : An Empirical Investigation. Marketing Investigation and Planning. 2000.

[11] Ghozali, Imam. Application of Multivariate Analysis with SPSS, Print. Fourth, the Publisher Agency of Diponegoro University. Semarang. 2006.

[12] Gilbert, David.. Retailing Marketing Management. $2^{\text {th }}$ Edition. England,. Edinburgh Gate: Pearson Educated Limited. 2003

[13] Griffin, Customer Loyalty :Loyalty is defined as non random purchase expressed overtime by some decision making unit. Jakarta: Erlangga. 2009.

[14] Hafeez Cheruvu VK, Haqqi T..The Impact Of Service Quality, Customer Satisfaction and Loyalty Programs on Customer's Loyalty: Evidence from Objek Wisata Brastagi Sumatera Utaraing Sector of 
Pakistan, International Journal of Business and Social Science Vol. 3 2012

[15] Hainz, Christa; Wiegand, Manuel.. How Does Relationship Objek Wisata Brastagi Sumatera Utaraing Influence Credit Financing? Evidence From The Financial Crisis. How does relationship Objek Wisata Brastagi Sumatera Utaraing influence credit financing? Evidence from the financial crisis, Ifo Working Paper, No. 157. 2013

[16] Hart dan Rosenberger, J.. The Effect Of Corporate Image In The Formation Of Customer Loyalty: An Australian Replication. Australasian Marketing Journal, Vol. 12, No. 3. 2004

[17] Info Objek Wisata Brastagi Sumatera Utara, Biro Riset 2008. Rating 98 Objek Wisata Brastagi Sumatera Utara di Indonesia Majalah InfoObjek Wisata Brastagi Sumatera Utara, No. 75:20-21. per April 2005-2008.

[18] Kandampully, Hsin-Hui (Sunny) Hu, Jay \& Thanika Juwaheer. 2009. Relationships and impacts of service quality, perceived value, customer satisfaction, and image: Jurnal Administrasi Bisnis (JAB) | Vol. 6 No. 2 December 2013 | administrasibisnis.studentjournal.ub.ac.id. An empirical study. The Services Industries Journal. Vol. 29, No.2, February 2009, 111-125.

[19] Karo Regency in Figures BPS Statistics of Karo Regency. (2016),

[20] Kartika Sari, Didin, The Effect Of Consumer Behavior On Purchase Decision (Research On Business Administration Student Force 2012/2013 Faculty Of Administrative Sciences Brawijaya University Consuming Indomie Instant Noodle Products), Business Administration Journal. Vol. 3. No.2,2013.

[21] Kotler, Philip, Principles of Marketing, Fifth Edition, Prentice Hall International, Engelwood Cliffs. 2001.

[22] $\longrightarrow$ Philip. Marketing Principles. Volume-1, Edition-8, Erlangga, Jakarta, 2009.

[23] Keller. Marketing Management, Issue 12. Publisher: Erland. Jakarta, 2009.

[24] Amstrong. Principles of Marketing. Pearson Education Limited. New Jersey, 2012.

[25] Kuncoro Mudrajad. Research Methods for Business and Economics: How to Research and Write Thesis ?, Publisher: Erland, Jakarta. 2003.

[26] Lamb, Charles W, Joseph F. Hair, and Carl McDaniel,. Marketing, Book 2, Translator: David Octarevia, First Edition, Publisher Salemba Four: Jakarta, 2004

[27] Liu, Tsug-Chi and Li Wei Wu. Customer retention and cross-buying in the Objek Wisata Brastagi Sumatera Utara in industry: An Integration of service attributes, satisfaction and trust. Journal of Financial Service Marketing, Vol. 12 No. 2 p. 132-145, 2007.

[28] Lupiyoadi, Rambat. and A. Hamdani. Marketing Management Services. Second Edition. Jakarta: Salemba Four, 2001.

[29] Mokhtar Amjad D Al-Nasser;Nooreha Husain. The Relationship Between Service Quality and Satisfaction on Customer Loyalty in Malaysian Mobile CommunicationIndustry. Journal School of Doctoral Studies European Union, 2011.

[30] McKeown, P. G. (2002). Information technology and the networked economy. Pennsylvania: Course Technology.

[31] Murray at all, The open Book of social innovation, Social Inovator Series : way to design, develop and grow social inivastion, The Young Fundation, 2010.

[32] Omboi dan Wangai, Factors that Influence the Demand for Credit for Credit Among Small-Scale Investors: a case study of Meru Central District, Kenya. Research Journal of Finance and Accounting www.iiste.org ISSN 2222-1697 (Paper) ISSN 2222-2847 (Online) Vol 2, No 2, 2011.

[33] Poluan. Analysis of the effects of product innovation and upcoming innovations towards consumer purchase decisions (casestudies onconsumers of Nokia mobile phones) Thesis. (2009).

[34] Peter,P.J; Olson,J.C; Consumer Behaviour and Marketing Strategy, McGraw - Hill Higher Education,7th Edition, 2005,

[35] Reymas, Herradi Fepria, (2009), "Analysis of the Influence of Brand Image, PerceptionAgainst Quality, Brand Name, and Brand Awareness To Purchase Soap Bath Decision At Lifebouy at Ungaran ",Essay ot published ,Faculty of Economics, Diponegoro University, Semarang.National Journal.

[36] Schiffman dan Kanuk. Customer Behaviour, Second Edition, .Jakarta, Indeks Gramedia, 2007.
[37] Sivesan. Service Quality and Customer Satisfaction: A Case Study Objek Wisata Brastagi Sumatera Utaraing Sectors in Jaffna District, Sri Lanka. International Journal of Marketing, Financial Services \& Management Research. Vol.1 Issue 10, October 2012.

[38] Sugiyono. Business Research Methods. Sixth Mold. Bandung: Alfabeta. 2008.

[39] Sumarni, Murti and John SoeprihantoIntroduction to Business. Liberty. Yogyakarta, 2005.

[40] Supranto, J. Satisfying Efforts to Be Loyal. Journal of Economics and Business, Vol.2 No.1, 2002

[41] Swastha, Basu and Ibnu Sukotjo. Introduction to Modern Business. Sixth Edition ,. Yogyakarta, 2007.

[42] Tjiptono, Fandy, Marketing Strategy, second edition, Andi ,. Yogyakarta, 2004,

[43] Toba Samosir, Regency in Figures BPS Statistics of Toba Samosir Regency. (2016),

[44] Turkyilmaz, Ali and Coskun Ozkan.. Development of a customer satisfaction index model. Industrial Management \& Data Systems, Vol. 107 No. 5 p. 627-687, 2007

[45] Walsh, Gianfranco, Keith Dinnie and Klaus-Peter Wiedmann. How do corporate reputation and customer satisfaction impact customer defection? A study of private energy customers in Germany. Journal of Services Marketing, Vol. 20 No. 6, p. 412-420, 2006. 